\title{
Sustainable Practices and Business Performance: Evidence from Sri Lankan Manufacturing Firms
}

\author{
Lalith Nimal Senaweera $^{1 *} \quad$ Mohd Shukri Ab Yajid $^{2} \quad$ Ali Khatibi $^{2} \quad$ S. M. Ferdous Azam ${ }^{2}$ \\ 1.Former Chairman, Consumer Affairs Authority, No 31, Mallikarama Road, Ratmalana, Sri Lanka \\ 2. Post Graduate School of Management, Management \& Science University, Malaysia
}

\begin{abstract}
The purpose of this paper is to investigate the influence of sustainable practices (SP) on business performance (BP) of ISO 14001 EMS certified manufacturing firms of Sri Lanka and also to examine the moderator effect from firm size on the link between sustainable practices and business performance. The study used the questionnaire survey technique to collect data from a sample selected using simple random sampling from known population and SPSS software is used for survey data analysis. The major finding indicates that sustainable practices have a positive influence on business performance and it can be measured using environmental practices, corporate governance, and human resource management practices. Moreover, the results indicate firm size has no moderating effect on the link between sustainability practices and business performance. The findings of this paper is a novelty for Sri Lankan manufacturing industry and for policymakers as it provides new insights to the manufacturing industry on sustainable practices(SP) and the business performance (BP). Moreover, the results of the study is useful for manufacturing firms in Sri Lanka looking forward to install ISO 14001 based environmental management system within the firms as results provide areas need to be focused. This research is confined to ISO 14001 EMS certified manufacturing firms of Sri Lanka and therefore the findings obtained may not be generalized to other countries.
\end{abstract}

Keywords: Sustainable Practices, Business Performance, Environmental Practices, Human Resource Management Practices, Corporate Governance

DOI: $10.7176 / \mathrm{EJBM} / 12-5-09$

Publication date: February $29^{\text {th }} 2020$

\section{Introduction}

With the new development of global trends, complex products, emerging of new markets, the serious global environmental issues, and the unprecedented depletion of resources has given serious attention in the $21^{\text {st }}$ century for sustainability and sustainable development with the intention of safeguarding the planet for future generations. According to Fabio (2017) the new perspective of sustainability bypass the "ecological" and "socio-economic" functions ensuring the sustainable improvement and comfort of individuals, groups, and organizations. Furthermore, Sommer (2012) pointed out in management leaders are identified as "change agents" but it is still not clear the reasons of integrating social engagement or principles of sustainability as part of the business models. Anyhow, (Zollo et al., 2013) indicated that many research titles "related to the processes through which firms actually navigate the multiple change requirements to identify, experiment with and eventually realize more sustainable models of the enterprise" but that has not yet developed. Venkatraman and Nayak (2010) indicated that the research findings show differences in the actual practice of sustainability. In other words, firms are working in an isolation manner with respect to economic, social and environmental issues within the firm without having an integrated approach. According to Seuring and Gold (2013), the sustainability management included the stakeholders and their demands and many previous studies show that those demands are very vital for driving sustainability performance. In other words, the firms' will not take any initiative to implement sustainable practices to meet obligatory requirements, however, the concern for sustainable development contributes to the firm competitiveness and economic performance creating a path for key stakeholders' satisfaction (Alfred \&Adam ,2009). The necessity of having an energetic sustainability is concentrated (Amui et al., 2017)

Sri Lanka being a country having local and export-based industries are given more focused attention to have sustainability practices within the manufacturing firms as that contribute a sizable amount for GDP of the country and therefore manufacturing sector is one of the important sectors in Sri Lanka. Moreover, in Sri Lanka manufacturing firms are concerned about the certification against ISO 14001 environmental management system and there is a positive trend in installing systems as per the said standard. The influence of ISO 14001 on firm emission performance relies on the firm's capability to constantly update its resources and operational capabilities to keep pace with the changing environment (Russo, 2009). Continuing scholar found that early adoption of ISO 14001 to be associated with lower emissions; the longer a facility operates ISO 14001, the lower its emissions. Moreover, in Russo's (2009) empirical study, early adoption of ISO 14001 and the continued use of pathdependent learning to strengthen the application are considered as crucial ways to build dynamic capabilities.

Even though Sri Lankan manufacturing firms have taken positive initiatives to proceed in obtaining ISO 14001 environmental management system certification as a step towards sustainability there were little studies 
done in the Sri Lankan context to determine whether within these firms really there is any effect on business performance in view of practicing functions as per the ISO 14001EMS. Therefore, this paper aims are to (1) determine the influence of corporate governance on business performance (2) find out the human resource management practices on business performance and (3) find out the environmental practices on business performance.

\section{Literature Review}

The examination of literature also revealed that there are barriers for sustainability practices and according to Rompa (2011), the lack of knowledge, capacity for sustainable policies, lack of top management commitment, and also the sustainable practices are not in the forefront of the organizations may not provide the competitive advantage. According to Carroll and Shabana (2010), the necessity of conducting social responsible activities as indicated in the extant literature over the years which lead to a situation of creating this topic in the academic study. Moreover, according to Closset al. (2011), "sustainability" has considered as a strategic objective by worldwide organizations.Moreover, Bansal (2005) indicated sustainability needs to have a business mechanism providing the necessity of consideration on the influence related to "economic", "environmental" and "social implications" for present and coming generations.

In this connection, Closs et al. (2011) indicated that sustainability means that every organization should take the responsibility of not damaging the ecosystem or making any harm to people in the society. The definition provides the necessity of having a three-dimensional approach for organizations going towards sustainability. According to Haffar and Searcy (2017), firms have extended the borders to cover economic, environmental, and social sustainability rather than just focusing on short term monetary benefits.

This may have a connection of introducing the well-accepted three pillars for sustainability as "Social", Economic" and "Environment introduced by (Elkington,1998). The concept covers people, planet and profit where each item can be connected to the three different broad-based dimensions described above. In other words, "Social", Economic" and "Environment" relatedoutcomes and opportunities are directly having a link with the above-mentioned 3Ps.Gimenez et al. (2012) indicated that "triple bottom line concept" provides the firms can obtain favorable benefits if those firms behave in "environmentally" and "socially responsible" manner. However, Venkatraman and Nayak (2010) mentioned that since most of the organizations follow the three pillars of Triple Bottom Line (TBL), a gap is identified between actual work of sustainability and the concept but no investigations have done to ascertain the interconnections.

The environmental and social responsibility is also considered on individual basis however, the manner of integrating environmental and social responsibility has a limited scope (Ashby et al., 2012). In other words, converting the concept into reality, i.e. into sound new actions, remains highly demanding. Furthermore, the corporate sustainability is the missing element of the corporate strategy and needs to be contemplating in strategic decisions (Bonn \& Fisher, 2011). Moreover, Busse (2016) and Chernev and Blair (2015) mentioned that by developing results-oriented strategies to change the organizations for more responsible ones shall become increasingly give more attention to environment and social aspects than a mere focus for future markets. Sacconi (2012) indicated as per agency theory agents are considered as "opportunists and will solicit to capitalize the interest of them than the interest of shareholders. According to Hahn and Kühnen (2013), the details reported in the sustainability reports by different companies are varying in both the content and nature in a considerable manner due to non-availability of regulation.

Penrose (1959), Resource-Based View (RBV) theory indicates that organization internal resources are unique, worth, and scarce and therefore leads to a sustainable competitive advantage paving the way to improve performance by having proper human resource practices which in turn support to implement sustainable practices. Similarly, Barney (2001) suggests that the Resource-Based View (RBV) theory proposes to maintain a human resource pool better than competitors as one of the vital factors that a firm need to do to maintain the sustainable competitive advantage.

Considering the academic perspective, a number of studies have applied different ways to measure business performance (Antony and Bhattacharyya, 2010). Furthermore, Aras et al. (2010) indicated that review of literature reveals that "Return On Equity" (ROE) has been used as an accounting measure. Similarly, the same scholar indicated that "Return On Sales" (ROS) has also been considered widely in the literature as an accounting measure.Moreover, it was argued that it is not sufficient to use one indicator to evaluate the total performance of a firm (Abas \&Yaacob, 2006). A combination of monetary and non- monetary indicators can be used to measure the performance (Tangen, 2003). Furthermore, some authors visualize mentally that performance can be categorized like financial/monetary gain such as "profit", "market share", "cost reduction" and non-monetary gains such as customer satisfaction, quality improvement, delivery performance and employee satisfaction (Verma \&Young, 2000).

Organizations' commitment to build competitive resources in their operating system using an environmental management system standard is therefore associated with the triple bottom line performance benefits: 
environmental, social, and market benefits (Prajogo et al., 2012). Borowy (2013), and Dyllick and Muff (2016) mentioned with the increasing adoption of sustainability by businesses the environment matters declining in a faster manner.

\subsection{Sustainability Practices}

'Sustainability Practices' become one of the vital concepts like the use of such practices within the firms provide tangible results. According to Sarkis (2001), the manufacturing firms' functions have been evolved over the years with regard to environmental practice and strategies and those are always the priority issues in the agenda of such firms' paving the way to handle the environmental sustainability. With the establishment of internationally recognized Global Reporting Initiative (GRI) guidelines, the usage of that has grown up and becomes very popular for documenting of sustainable practices (Garcia et al., 2016; Thijssens et al., 2016)

According to Boons and Lüdeke-Freund (2013), an increasing trend of investigations are carried out by many intellectuals and practitioners to determine the possibility of changing the existing business models or developing new models in order to reduce the negative external impact for the environment and the society leading to a wealthy economy.Dhaliwal et al. (2011) concluded that socially responsible practices may lead to long term financial returns to the firm. Kurapatskie and Darnall (2013) indicated that sustainability practices were connected with the sustainability performance with varying strength and time horizon.Carrol (1999) mentioned that the connections of social and financial performance are shown widely linked with the models having the concept of corporate social responsibility.

Considering the environmental issues and the GHG Gas matters taking place globally manufacturing firms have taken positive aspects to implement sustainable practices. Moreover, Whiteman et al. (2013) indicated that organizations having donations for "sustainable development" of the economy and society by having a coherent mechanism using "social", "environmental", and "economic" factors are identified as "sustainability management". Wagner (2010); Orlitzky et al., (2003) indicated that a Corporate Sustainability (CS) have a considerable influence on economic enhancement and competitiveness. Furthermore, Orlitzky et al., (2003) indicated that most of the studies showed that corporate social responsibility practices have positive influence on business performance. At the same time according to Margolis and Walsh (2003), there were studies that showed no conclusion about the connection between corporate financial performance and corporate social responsibility. In view of the above, the following hypothesis is proposed.

$\mathrm{H}_{1}$ Sustainable Practices has an influence on Business Performance

\subsection{Corporate Governance and Business Performance}

Ntim et al. (2013), Jizi et al. (2014) and Allegrini and Greco (2013) proved empirically that board size and level of disclosure positively related. Jensen and Meckling (1976), indicated that one of the important factors of sustainability dimension as per Agency theory is Corporate Governance and there should be a positive relationship between corporate governance and firm performance.Corporate governance and firm financial performance association in evolving markets are empirically proved (Aguilera et al., 2011). Good corporate governance and a firm financial performance are correlated (Renders et al., 2010). No conclusion was made about the positive relationship between corporate governance and firm performance (Gupta, Chandrasekhar, Tourani-Rad, 2013). Considering the above, the following hypothesis was proposed.

Hypothesis $\left(\mathrm{H}_{1 \mathrm{a}}\right)$ : Corporate Governance has a positive influence on business performance.

\subsection{Human Resource Management Practices and Business Performance}

One of the main important thing to remove barriers for sustainable practices with a considerable commitment is to have an improved communication and training and development of employees as it supports to change the attitude and encourage for involvement (Stone, 2006).In furtherance Linnenluecke and Griffiths (2010) mention that ultimately these initiatives make the "green" or "sustainable organizational culture". Once the top Management got involved in the sustainability work then the concept can be facilitated within the organization (Bansal, 2003). Similarly, K'Obonyo, Busienei, and Ogutu (2013) indicated the examination of previous research studies reveal that the firms implement certain human resource practices, policies show excellent results when compared to competitors. Moreover, Stoughton and Ludema (2012) indicates that currentresearch findings reveal that commitment of top management plays a vital role in implementing sustainability within thefirm.Moreover,Busienei (2013) proved that HRM practices contribute significantly for firm performance. Considering the above, the following hypothesis was proposed.

Hypothesis $\left(\mathrm{H}_{1 \mathrm{~b}}\right)$ : Human Resource Management Practices have a positive influence on business performance.

\subsection{Environmental Practices and Business Performance}

The scholars Berrone et al. (2013), Colwell and Joshi (2013) and Moon et al. (2014) indicated for research work on environmental protection activities Institutional Theory provides a good outlook. Young and Tilley (2006) 
indicated that at business level the focus towards sustainability practices has shifted from "pollution control" to "eco-efficiency" and "socio-efficiency". Main purpose is to have a win-win situation where environmental performance such as minimization of "resource consumption" and "waste generation" are connected to economic benefits whereas reducing of negative social impacts or increasing of positive ones are linked with the social performance.According to Smith (2012), manufacturing firms are pressurized to use less resources to manufacture more green products having low waste generation and less pollution to meet the ever-changing quality of life of people. It could, therefore, be argued that environmental sustainability could contribute both to economic profitability and competitive advantages (Wagner, 2005).According to Kang and Lee (2016), whether there is a causal positive or negative relationship between environmental strategy and company performance is one of the most favorite concern of the studies related to environmental sustainability development.

Hence the following hypothesis is proposed.

Hypothesis $\left(\mathrm{H}_{1 \mathrm{c}}\right)$ : Environmental Practices have a positive influence on business performance.

\subsection{Moderating role of Firm Size}

Firm size shows the capacity According to Temtime (2003), the development and execution of strategies want commitment of insufficient resources as the firm size provides the resource funding that is connected with the planning. Gimenez et al. (2012) proved that the performance of the firm varies according to the firm size.

$\mathrm{H}_{2}$ :Firm Size moderates the relationship between sustainable practices and business performance

Considering the foregoing information, the following hypothesized model is proposed to evaluate the sustainable practices of ISO 14001 EMS certified Sri Lankan manufacturing firms in Sri Lanka. The ISO 14001 EMS certified manufacturing firms are considered for the study and used three dimensions in assessing the hypothesized model used for this study.

\begin{tabular}{|l|l|l|}
\hline \multicolumn{1}{|c|}{ SUSTAINABLE PRACTICES } \\
Corporate Governance \\
Human Resource Management Practices \\
Environmental Practices
\end{tabular}

Figure 1- Hypothesized Model

\section{Methodology}

3.1 Pilot Study

A well-structured questionnaire was developed based on the comprehensive literature review findings using previously validated items by different scholars and questions were categorized under each dimensionswith a 5 point Likert scale. There were three sections in the questionnaire with 53 questions. The questionnaire was pretested with the support of the knowledgeable personnel and then distributed it among randomly selected 20 manufacturing firms and based on the findings the certain items of the questionnaire were modified. The reliability of data was ensured by conducting Cronbach's Alfa value tests.

\subsection{Population and Sampling}

Population of the study obtains from the ISO 14001 environmental Management Systems certified manufacturing firms of Sri Lanka. Simple random sampling technique was used to select the sample using Sekaran and Bougie (2016) sampling tables and also consideration was given to response rate for the pilot study to select the corresponding sample size of 151 manufacturing firms. The main respondents to this study were managing director, senior directors, managers, executives who have thorough knowledge and experience in the applicationof ISO 14001 environmental management system concepts within the manufacturing firms. After reviewing the received questionnaires, for the study 138 usable questionnaires were used.

\subsection{Data Analysis Techniques}

The study used the SPSS software 21 version for the analysis of data and a number of tests such as screening for missing data, normality tests, validity \& reliability test, Descriptive statistics analysis, Linearity test, homogeneity test, multicollinearity tests were performed and checked the suitability of data for further analysis. Then for the analysis of hypotheses, multiple regression and hierarchical regression analysis techniques were used. 
4 Results and Discussion

4.1 Profile of the Respondents

Table 1 Educational Qualifications

\begin{tabular}{|l|l|l|}
\hline Educational Qualification & Frequency & Percent \\
\hline $\mathrm{O} / \mathrm{L}$ & 1 & .7 \\
\hline $\mathrm{A} / \mathrm{L}$ & 25 & 18.1 \\
\hline Trade Certificate & 70 & 50.7 \\
\hline Degree & 42 & 30.4 \\
\hline Total & 138 & 100 \\
\hline
\end{tabular}

Note: Survey Data, 2019

As per the analysis and the results given above in table 1 about $50.7 \%$ are having trade certificates and $30.4 \%$ are degree holders. This indicates that $81.1 \%$ of the respondents are well qualified in the respective fields. In other words, this infers that the respondents are knowledgeable and having an understanding about the functions of the firms.

Table 2 Work Experience in years

\begin{tabular}{|l|l|l|}
\hline Work Experience & Frequency & Percentage \\
\hline $3-5$ & 11 & 8 \\
\hline $6-8$ & 56 & 40.6 \\
\hline $9-10$ & 48 & 34.8 \\
\hline 10 above & 23 & 16.6 \\
\hline Total & 138 & 100 \\
\hline
\end{tabular}

Note: Survey Data, 2019

The above analysis given in table 2 shows that $92 \%$ respondents are having six or over six years working experience and hence majority of respondents are very knowledgeable about the actual practices of these firms. This indicates that the to a very great extent survey answers are sound.

\subsection{Hypothesis Testing}

\subsubsection{Results of Reliability Analysis}

The reliability analysis of survey data was done by calculating the Cronbach's Alfa vale. The results of analysis were given below in table 3. Cooper and Schindler (2008) indicated that if Cronbach's Alfa value is greater than 0.7 the data is reliable. As per the results for all dimensions the Cronbach's Alfa was above 0.7 hence the data is reliable and can be used for further analysis. given below showed the results of reliability analysis of data. Since Cronbach's alfa value for all dimensions are over 0.7 the data are reliable and can be used for further analysis.

Table 3 Summary of Reliability Tests of data collected

\begin{tabular}{|l|l|l|}
\hline Variable & Cronbach's Coefficient scores & Alfa Interpretation (>0.7) \\
\hline Corporate Governance & 0.741 & Reliable \\
\hline Environmental Practices & 0.701 & Reliable \\
\hline HRM Practices & 0.715 & Reliable \\
\hline Business Performance & 0.732 & Reliable \\
\hline
\end{tabular}

Note: Survey data 2019

A multiple regression analysis was conducted to test the hypotheses of $\mathrm{H}_{1}$ and sub -hypotheses $\mathrm{H}_{1 \mathrm{a}}$ to $\mathrm{H}_{1 \mathrm{c}}$ Moreover, hierarchical regression analysis was done to test the hypothesis $\mathrm{H}_{2}$. The results are shown below:

Table 4 Multiple regression analysis of the effect of Sustainable practices on business performance

\begin{tabular}{|l|l|l|l|l|l|l|l|l|}
\hline dimensions & $\mathrm{R}$ & $\mathrm{R}^{2}$ & $\begin{array}{l}\text { Adjusted } \\
\mathrm{R}^{2}\end{array}$ & $\begin{array}{l}\mathrm{F}- \\
\text { value }\end{array}$ & $\mathrm{Sig}^{*}$ & $\begin{array}{l}\text { Standardized } \\
\text { Beta }\end{array}$ & $\begin{array}{l}\mathrm{t}- \\
\text { value }\end{array}$ & \begin{tabular}{l} 
Sig*. \\
\hline
\end{tabular} \\
\hline & 0.526 & 0.277 & 0.250 & 10.116 & $0.000^{*}$ & & & \\
\hline Corporate Governance & & & & & & 0.224 & 2.550 & $0.012^{*}$ \\
\hline Environmental Practices & & & & & & 0.025 & 0.287 & 0.775 \\
\hline $\begin{array}{l}\text { Human Resource } \\
\text { Management Practices }\end{array}$ & & & & & & 0.208 & 2.561 & $0.012^{*}$ \\
\hline
\end{tabular}

Note: Survey Data, 2019.

The table 4 above shows the $\mathrm{R}^{2}$ value of 0.277 , that indicates the model is suitable with the data for application of multiple regression analysis. The R-value of correlation coefficient is 0.526 indicates that Sustainable Practices and Business Performance are having a positive correlation. The results of the multiple regression analysis show that the three dimensions' together explained $27.7 \%$ of the variance, where $\left(\mathrm{R}^{2}=0.277, \mathrm{~F}=10.116\right.$, Sig. $\left.=0.000\right)$. Since the p-value is less than 0.05 , the alternative hypothesis is accepted, which provides that there is a weak contribution of Sustainable Practices (Corporate Governance, Environmental Practices, and Human Resource Management Practices) on Business performance, at level $(\alpha \leq 0.05)$. This finding is in line with the results of 
Dhaliwal et al. (2011) which indicates that sustainability practices contribute to enhance business performance.

Furthermore, Hypothesis $\mathrm{H}_{1 \mathrm{a}}$ is supported as $(\mathrm{Beta}=0.224$, sig. $=0.012)$ that means $\mathrm{p}$ is less than 0.05 and in other words, this indicates that corporate governance has a weak positive influence on business performance, at level $(\alpha \leq 0.05)$. This provides that corporate governance plays an important role on enhancing business performance and the finding is also consistent with the previous research findings of Renders et al. (2010) The Hypothesis $\mathrm{H}_{1 \mathrm{~b}}$ is supported as $(\mathrm{Beta}=0.208$, sig. $=0.012)$ that means $\mathrm{p}$ is less than 0.05 and therefore human resource management practices have a weak positive influence on business performance at level $(\alpha \leq 0.05)$. This finding is also supported with Busienei (2013). In furtherance, $\mathrm{H}_{1 \mathrm{c}}$ is not supported as $(\mathrm{Beta}=0.025$, sig. $=0.775)$ that means $\mathrm{p}$ is greater than 0.05 and that indicates the environmental practices have no positive influence on business performance as per the analysis results.

Table 5 Hierarchical regression results using firm size as a moderator

\begin{tabular}{|l|l|l|l|}
\hline dimensions & $\begin{array}{l}\text { Std. Beta Model } \\
1\end{array}$ & Std. Beta Model 2 & Std. Beta Model 3 \\
\hline Corporate Governance & 0.224 & 0.219 & 0.882 \\
\hline Environmental Practices & 0.025 & 0.008 & 0.155 \\
\hline Human Resource Management Practices & 0.208 & 0.213 & 0.451 \\
\hline Firm Size & & 0.075 & 1.794 \\
\hline CG*F & & & -1.795 \\
\hline EP*F & & & -.564 \\
\hline HRM*F & & & -.809 \\
\hline $\mathrm{R}^{2}$ & 0.277 & 0.282 & 0.333 \\
\hline Adj. $\mathrm{R}^{2}$ & 0.250 & 0.249 & 0.274 \\
\hline $\mathrm{R}^{2}$ change & 0.277 & 0.005 & 0.050 \\
\hline Sig F Change & $0.000^{*}$ & 0.331 & 0.098 \\
\hline
\end{tabular}

$* * \mathrm{p}<0.01 \quad \mathrm{p}^{*}<0.05 \quad \mathrm{~N}=138$; Standardized coefficients are presented

The above table 5 of hierarchical linear regression indicates in Model 1, R Square value of .277 and when Firm size scores were added as shown in Model 2, the value for R Square increased to .282 (28.2\%)leading to a difference of 0.005 which means with addition of Firm Size scores contributes $0.05 \%$ additional variance in business performance. On the same basis when other interaction variables were added in Model 3 the value for R square increased to $0.333(33.3 \%)$ having an increase of 0.050 giving an additional $0.5 \%$ variance in business performance. Furthermore, in Model 2, $\beta$ value of firm size $(0.075)$ and in Model 3, $\beta$ values for interaction variables are $-1.795,-0.564 \&-.089$ are not significant. Moreover, when consider the above results only Model 1 is Sig. F Change is less than 0.001 and hence this indicated with the addition of new variable do not produce statistically increase invariance for the dependent variable of business performance. Therefore, $\mathrm{H}_{2}$ is not supported. Hence firm size has no moderating effect on the relationship between sustainability practices and business performance.

\section{Conclusions}

In summary sustainability practices have an influence on business performance of the ISO 14001 environmental management system certified manufacturing firms. Moreover, corporate governance of the firm is important as per the analysis to enhance business performance. This is a very important finding as board of directors' are the decision-making body of any firm and therefore their support is very much required to adopt sustainable practices leading to enhance business performance of the firm. Furthermore, the analysis revealed that human resource management practices also support to enhance business performance. In other words, the results of the study suggest to focus on human resource management practices as it is vital for manufacturing firms to enhance the business performance. Surprisingly, study revealed that one of the sustainable practices namely environmental practices do not have a contribution for business performance. Since the research has been done using the manufacturing firms certified to ISO 14001 environmental management system in Sri Lanka and therefore the respondents of these firms are well aware about the actual situation of the environmental practices of these firms. Hence study suggests that the CEOs' of these firms should give considerable attention to the implementation of ISO 14001 based environmental practices within these firms to gain the real benefits.

Moreover, findings indicate that firm size has no moderating effect on the relationship between sustainable practices and business performance. This indicates irrespective of the firm size the ISO 14001 environmental management system certified manufacturing firms can use sustainable practices to enhance business performance. In furtherance, the firm size is not a factor to consider when implementing sustainable practices within the ISO 14001 environmental management system certified manufacturing firms.

\subsection{Research Limitation}


This study was limited to ISO 14001 certified manufacturing firms in Sri Lanka and therefore results are applicable only to such manufacturing firms. Moreover, the study used a Likert based questionnaire and hence the respondents have no choice other than select one of the answers which limit to obtain the real ground situation of the firms.

\subsection{Future Research Direction}

The future research may be expanded to specific sectors such as Food, Ruber, health and education with a larger sample which would further improve the results having an uniqueness to specific sector. Moreover, future research can also focus on selecting a specific category of manufacturing firms like large, medium or small as that would enable to make unique recommendations to that category of firms.

\section{References}

Abas, Z., \&Yaacob, Z. (2006). Exploring the relationships between total quality management (TQM), strategic control systems (SCS) and organizational performance (OP) using a SEM framework. The Journal of American Academy of Business, Cambridge, 9(2), 161-167.

Alfred, A. M., \& Adam, R. F. (2009). Green management matters regardless. Academy of Management Perspectives, 23(3), 17-26.

Allegrini, M., \& Greco, G. (2013). Corporate boards, audit committees and voluntary disclosure: Evidence from Italian listed companies. Journal of Management \& Governance, 17(1), 187-216.

Amui, L. B. L., Jabbour, C. J. C., de Sousa Jabbour, A. B. L., \& Kannan, D. (2017). Sustainability as a dynamic organizational capability: a systematic review and a future agenda toward a sustainable transition. Journal of Cleaner Production, 142, 308-322.

Antony, J. P., \& Bhattacharyya, S. (2010). Measuring organizational performance and organizational excellence of SMEs-Part 2: an empirical study on SMEs in India. Measuring business excellence.

Aras, G., Aybars, A., \&Kutlu, O. (2010). Managing corporate performance. International Journal of productivity and Performance management.

Ashby, A., Leat, M., \& Hudson-Smith, M. (2012). Making connections: a review of supply chain management and sustainability literature. Supply Chain Management: An International Journal.

Aguilera, R. V., Desender, K. A., \& De Castro, L. R. K (2011). A configurational approach to comparative corporate governance. Sage Handbook of Corporate Governance, New York. DOI. 10.2139/ssrn.1797142

Bansal, P. (2003). From issues to actions: The importance of individual concerns and organizational values in responding to natural environmental issues. Organization Science, 14(5), 510-527.

Bansal, P. (2005). Evolving sustainably: A longitudinal study of corporate sustainable development. Strategic management journal, 26(3), 197-218.

Barney, J. B. (2001). Resource-based theories of competitive advantage: A ten-year retrospective on the resourcebased view. Journal of Management, 27(6), 643-650.

Berrone, P., Fosfuri, A., Gelabert, L., \& Gomez-Mejia, L. R. (2013). Necessity as the mother of 'greeninventions: Institutional pressures and environmental innovations. Strategic Management Journal, 34(8), 891-909.

Bonn, I., \& Fisher, J. (2011). Sustainability: the missing ingredient in strategy. Journal of business strategy.

Boons, F., \&Lüdeke-Freund, F. (2013). Business models for sustainable innovation: state-of-the-art and steps towards a research agenda. Journal of Cleaner Production, 45, 9-19.

Borowy, I. (2013). Defining sustainable development for our common future: A history of the World Commission on Environment and Development (Brundtland Commission). Routledge.

Busienei, J. R. (2013). Effect of Business Strategy and Organizational Structure on the Relationship between Human Resource Strategic Orientation and Performance of Private Manufacturing Firms in Kenya. Unpublished Ph. D Thesis), University of Nairobi.

Busse, C. (2016). Doing well by doing good? The self-interest of buying firms and sustainable supply chain management. Journal of Supply Chain Management, 52(2), 28-47.

Carroll, A. B. (1999). Corporate social responsibility: Evolution of a definitional construct. Business \& society, $38(3), 268-295$.

Carroll, A. B., \&Shabana, K. M. (2010). The business case for corporate social responsibility: A review of concepts, research, and practice. International journal of management reviews, 12(1), 85-105.

Chernev, A., \& Blair, S. (2015). Doing well by doing good: The benevolent halo of corporate social responsibility. Journal of Consumer Research, 41(6), 1412-1425.

Closs, D. J., Speier, C., \& Meacham, N. (2011). Sustainability to support end-to-end value chains: the role of supply chain management. Journal of the Academy of Marketing Science, 39(1), 101-116.

Colwell, S. R., \& Joshi, A. W. (2013). Corporate ecological responsiveness: Antecedent effects of institutional pressure and top management commitment and their impact on organizational performance. Business Strategy and the Environment, 22(2), 73-91.

Cooper, D. R. \& Schindler, P. S. (2006). Business Research Methods, 9th Ed., Boston: McGraw-Hill \& Irwin 
Di Fabio, A. (2017). The psychology of sustainability and sustainable development for well-being in organizations. Frontiers in psychology, 8, 1534.

Dhaliwal, D. S., Li, O. Z., Tsang, A., \& Yang, Y. G. (2011). Voluntary nonfinancial disclosure and the cost of equity capital: The initiation of corporate social responsibility reporting. The accounting review, 86(1), 59100.

Dyllick, T., \& Muff, K. (2016). Clarifying the meaning of sustainable business: Introducing a typology from business-as-usual to true business sustainability. Organization \& Environment, 29(2), 156-174.

Elkington, J. (1998). Partnerships from cannibals with forks: The triple bottom line of 21 st-century business. Environmental quality management, 8(1), 37-51.

Garcia, S., Cintra, Y., Rita de Cássia, S. R., \& Lima, F. G. (2016). Corporate sustainability management: a proposed multi-criteria model to support balanced decision-making. Journal of Cleaner Production, 136, 181-196.

Gimenez, C., Sierra, V., \& Rodon, J. (2012). Sustainable operations: Their impact on the triple bottom line. International Journal of Production Economics, 140(1), 149-159.

Gupta, K., Krishnamurti, C., \&Tourani-Rad, A. (2013). Is corporate governance relevant during the financial crisis? Journal of International Financial Markets, Institutions, and Money, 23, 85-110.

Haffar, M., \& Searcy, C. (2017). Classification of trade-offs encountered in the practice of corporate sustainability. Journal of Business Ethics, 140(3), 495-522.

Hahn, R., \&Kühnen, M. (2013). Determinants of sustainability reporting: a review of results, trends, theory, and opportunities in an expanding field of research. Journal of cleaner production, 59, 5-21.

Jensen, M. C., \&Meckling, W. H. (1976). Theory of the firm: Managerial behavior, agency costs, and ownership structure. Journal of financial economics, 3(4), 305-360.

Jizi, M. I., Salama, A., Dixon, R., \&Stratling, R. (2014). Corporate governance and corporate social responsibility disclosure: Evidence from the US banking sector. Journal of business ethics, 125(4), 601-615.

Kang, S. W., \& Lee, K. H. (2016). Mainstreaming corporate environmental strategy in management research. Benchmarking: An International Journal.

K'Obonyo, P., Busienei, J. R., \&Ogutu, M. (2013). EFFECT OF UNIVERSALISTIC PERSPECTIVE OF HUMAN RESOURCE STRATEGIC ORIENTATION ON PERFORMANCE OF LARGE PRIVATE MANUFACTURING FIRMS IN KENYA. In AIBUMA Conference.

Kurapatskie, B., \&Darnall, N. (2013). Which corporate sustainability activities are associated with greater financial payoffs? Business strategy and the environment, 22(1), 49-61.

Linnenluecke, M. K., \& Griffiths, A. (2010). Corporate sustainability and organizational culture. Journal of world business, 45(4), 357-366.

Margolis, J. D., \& Walsh, J. P. (2003). Misery loves companies: Rethinking social initiatives by business. Administrative science quarterly, 48(2), 268-305.

Moon, S. G., Bae, S., \&Jeong, M. G. (2014). Corporate sustainability and economic performance: An empirical analysis of a voluntary environmental program in the USA. Business Strategy and the Environment, 23(8), 534-546.

Ntim, C. G., \&Soobaroyen, T. (2013). Black economic empowerment disclosures by South African listed corporations: The influence of ownership and board characteristics. Journal of business ethics, 116(1), 121138.

Orlitzky, M., Schmidt, F. L., \&Rynes, S. L. (2003). Corporate social and financial performance: A meta-analysis. Organization Studies, 24(3), 403-441.

Penrose, E. T. (1959). The Theory of the Growth of the Firm. New York: John Wiley \& Sons Inc. Penrose, E. T, $1,1-23$.

Prajogo, D., Tang, A. K., \& Lai, K. H. (2012). Do firms get what they want from ISO 14001 adoption? an Australian perspective. Journal of Cleaner Production, 33, 117-126.

Renders, A., Gaeremynck, A., \&Sercu, P. (2010). Corporate-governance ratings and company performance: A Cross-European study. Corporate Governance: An International Review, 18(2), 87-106.

Rompa, I. (2011). Explorative research on sustainable human resource management. Master's Thesis. University of Amsterdam.

Russo, M. V. (2009). Explaining the impact of ISO 14001 on emission performance: a dynamic capabilities perspective on process and learning. Business Strategy and the Environment, 18(5), 307-319.

Sacconi, L. (2012). Corporate social responsibility and corporate governance. EconomEtica, 38, 1-42.

Sarkis, J. (2001). Manufacturing's role in corporate environmental Sustainability-Concerns for the new millennium. International Journal of Operations \& Production Management, 21(5/6), 666-686.

Sekaran, U., \&Bougie, R. (2016). Research methods for business: A skill-building approach. John Wiley \& Sons.

Seuring, S., \& Gold, S. (2013). Sustainability management beyond corporate boundaries: from stakeholders to performance. Journal of Cleaner Production, 56, 1-6. 
Smith, A. D. (2012). Green supply chain management and consumer sensitivity to greener and leaner options in the automotive industry. International Journal of Logistics Systems and Management, 12(1), 1-31.

Sommer, A. (2012). Managing green business model transformations. Springer Science \& Business Media.

Stone, L. J. (2006). Limitations of cleaner production programs as organizational change agents. II. Leadership, support, communication, involvement, and program design. Journal of cleaner production, 14(1), 15-30.

Stoughton, A. M., \&Ludema, J. (2012). The driving forces of sustainability. Journal of Organizational Change Management, 25(4), 501-517.

Tangen, S. (2003). An overview of frequently used performance measures. Work-study, 52(7), 347-354.

Temtime, Z. T. (2003). The moderating impacts of business planning and firm size on total quality management practices. The TQM Magazine.

Thijssens, T., Bollen, L., \&Hassink, H. (2016). Managing sustainability reporting: many ways to publish exemplary reports. Journal of Cleaner Production, 136, 86-101.

Venkatraman, S., \&Nayak, R. R. (2010). A performance framework for corporate sustainability. International Journal of Business Innovation and Research, 4(5), 475-490.

Verma, R., \& Young, S. T. (2000). Configurations of low-contact services. Journal of Operations Management, $18(6), 643-661$.

Wagner, M. (2005). How to reconcile environmental and economic performance to improve corporate sustainability: corporate environmental strategies in the European paper industry. Journal of Environmental Management, 76, 105-118.

Wagner, M. (2010). The role of corporate sustainability performance for economic performance: A firm-level analysis of moderation effects. Ecological Economics, 69(7), 1553-1560.

Whiteman, G., Walker, B., \& Perego, P. (2013). Planetary boundaries: Ecological foundations for corporate sustainability. Journal of Management Studies, 50(2), 307-336.

Young, W., \& Tilley, F. (2006). Can businesses move beyond efficiency? The shift toward effectiveness and equity in the corporate sustainability debate. Business Strategy and the Environment, 15(6), 402-415.

Zollo, M., Cennamo, C., \& Neumann, K. (2013). Beyond what and why: Understanding organizational evolution towards sustainable enterprise models. Organization \& Environment, 26(3), 241-259. 